\title{
Brazilian research on cognitive impairment and dementia from 1999 to 2013
}

\author{
André Aguiar Souza Furtado de Toledo ${ }^{1}$, Ricardo Nitrini², \\ Cássio Machado de Campos Bottino ${ }^{3}$, Paulo Caramelli ${ }^{1}$
}

\begin{abstract}
The phenomenon of demographic transition in recent decades has increased the number of elderly people in Brazil, promoting an escalation in chronic-degenerative conditions, particularly dementia and cognitive related disorders. Objective: The aim of this study was to assess the evolution of the Brazilian scientific publications on dementia and related conditions from 1999 to 2013. Methods: Articles published during the analysis period were searched on three electronic databases: Scopus, Medline (via PubMed) and Lilacs (via BVS). The keywords used were Alzheimer's disease, dementia and mild cognitive impairment, with Brazil as the country of affiliation. Results: A total of 1,657 articles met the conditions for inclusion in the study. The output of Brazilian researchers in the area of cognitive disorders increased 11.38-fold in the fifteen-year period of analysis and 4.98-fold from 2003 to 2013. More than half of the articles (53\%) were published in international journals. The majority of institutions involved in publications were public universities while $19 \%$ were collaborative studies involving Brazilian and international institutions. Conclusion: Despite marked growth, the number of Brazilian scientific publications in the area of cognitive impairment and dementia is still low. More effort is required to improve the output of Brazilian researchers and institutions. Possible strategies to accomplish this increase could be to encourage residents to participate in publications of scientific papers during their residence program and to increase the collaborations between different institutions within Brazil and with the international scientific community.
\end{abstract}

Key words: dementia, mild cognitive impairment, Alzheimer's disease, scientific output, Brazil, Brazilian institutions.

\section{PESQUISA CIENTíFICA EM COMPROMETIMENTO COGNITIVO E DEMÊNCIA NO BRASIL DE 1999 A 2013}

RESUMO. 0 fenômeno da transição demográfica nas últimas décadas aumentou o número de indivíduos idosos no Brasil, promovendo um avanço de condições crônico-degenerativas, particularmente demência e outros distúrbios cognitivos relacionados. Objetivo: A intenção deste estudo foi avaliar a evolução da produção científica brasileira em demência e condições relacionadas de 1999 a 2013. Métodos: Pesquisamos artigos publicados durante esse período em três bancos de dados eletrônicos: Scopus, Medline (via PubMed) e Lilacs (via BVS). As palavras-chave utilizadas foram doença de Alzheimer, demência e comprometimento cognitivo leve, com o Brasil como país de afiliação. Resultados: Um total de 1.657 artigos cumpriram as condições para inclusão no estudo. A produção de pesquisadores brasileiros na área de distúrbios cognitivos aumentou 11,38 vezes no período de análise e 4,98 vezes de 2003 a 2013. Mais da metade dos artigos (53\%) foi publicada em periódicos internacionais. A maioria das instituições envolvidas em publicações eram universidades públicas e 19\% eram estudos colaborativos envolvendo instituições brasileiras e internacionais. Conclusão: Apesar do crescimento expressivo, 0 número de publicações cientificas brasileiras na área de comprometimento cognitivo e demência é ainda baixo. Mais esforços são necessários para melhorar a produção de pesquisadores e instituições brasileiras. Possiveis estratégias para cumprir essa tarefa poderiam ser encorajar residentes a participar de publicações de artigos científicos durante seu programa de residência e aumentar as colaborações entre diferentes instituições brasileiras e com a comunidade cientifica internacional. Palavras-chave: demência, comprometimento cognitivo leve, doença de Alzheimer, produção científica, Brasil, instituições brasileiras.

\section{INTRODUCTION}

The phenomenon of demographic transition occurring worldwide, including in Brazil over

recent decades, has produced a significant increase in the number of elderly people in the

'Departamento de Clínica Médica, Faculdade de Medicina da Universidade Federal de Minas Gerais, Belo Horizonte, MG, Brasil. ²Departamento de Neurologia da Faculdade de Medicina da Universidade de São Paulo, SP, Brasil. '² Departamento de Psiquiatria da Faculdade de Medicina da Universidade de São Paulo, SP, Brasil.

Paulo Caramelli. Av. Prof.Alfredo Balena, 190 / Sala 246 - 30130-100 Belo Horizonte MG - Brasil. E-mail:caramelliufmg.br

Disclosure: The authors report no conflicts of interest.

Received August 18, 2013. Accepted in final form November 03, 2014. 
Brazilian population. An important consequence of this process is an increase in chronic-degenerative conditions, particularly dementia and cognitive related disorders. The most common causes of dementia are Alzheimer's disease, vascular dementia, frontotemporal dementia and Lewy body dementia., ${ }^{1,2}$ Another major clinical condition is mild cognitive impairment (MCI), denoting a condition where cognition lies between normality and dementia and may be a precursor of dementia. ${ }^{3}$

According to a recent meta-analysis conducted in Brazil on the prevalence of dementia among elderly Brazilians, dementia was most prevalent among poor, illiterate, female and very elderly individuals, although overall prevalence could not be estimated due to wide variations in the Brazilian population throughout the country or due to methodological differences across the studies. ${ }^{4}$

Efforts to improve the quality and availability of care to patients affected by these conditions call for greater investment not only in the health system but also on research into pathology, genetics, clinical aspects, treatment and modifiable risk factors. ${ }^{5}$

Alzheimer's disease is the most prevalent neurodegenerative condition, representing the main cause of dementia worldwide and also in Latin America. ${ }^{6,7}$ Due to this epidemiological and also clinical relevance it is a major area of scientific research. Accordingly, publications on Alzheimer's disease represent around $17 \%$ of all neuroscience literature. ${ }^{8}$

The main objective of this study was to assess the extent and evolution of publications on cognitive impairment and dementia involving Brazilian institutions from 1999 to 2013 and to characterize this output considering regional and institutional distributions besides other aspects.

\section{METHODS}

The publications included were related to all types of dementia and mild cognitive impairment. Articles published from 1999 to 2013 were retrieved from electronic databases, including Scopus, Medline (via PubMed) and Latin American and Caribbean Health Sciences Literature (Lilacs, via BVS). The keywords were dementia, Alzheimer's disease and mild cognitive impairment (Table 1). Results were filtered to yield publications involving at least one Brazilian institution by using country of affiliation criteria.

Each paper was classified according to the following criteria: research type, name of periodical, year, Brazilian institution, state and collaboration type. Papers were then compiled in an Excel file. Institutions and states of collaborative publications were defined by the first Brazilian author in order of appearance in the list of authorship. The impact factor (IF) of each periodical was obtained from the Journal Citation Reports ${ }^{\circledR}$ (via ISI Web of Knowledge) and was also included in the Excel file. Periodicals not listed in the ISI Web of Knowledge had IF computed by SCImago Journal \& Country Rank (Powered by Scopus) using the same formula created by Thomson Reuters. Studies were excluded if not related to dementia or cognitive impairment, not completely fulfilling the search criteria or not involving a Brazilian institution.

\section{RESULTS}

A total of 2,523 articles were identified (Scopus: 1,449, Medline: 575, Lilacs: 499) of which 1,657 met the conditions for inclusion in the study (Figure 1 ).

Considering the first and the last year of this study, the number of publications rose more than $1038 \%$ in fifteen years, with a marked increase since 2007 (Table 2, Figure 2).

The majority of institutions involved in publications were public universities, featuring São Paulo University (USP), which was responsible for $29 \%$ of results (Figure 3). Concerning distribution throughout Brazilian states, institutions located in the southeast and south regions had a significant participation, representing $75 \%$ and $14 \%$ respectively (Figure 4).

Table 1. Electronic search strategy.

\begin{tabular}{|c|c|}
\hline Database & Search strategy \\
\hline Scopus & $\begin{array}{l}\text { KEY (“mild cognitive impairment" OR dementia OR "alzheimer disease") AND PUBYEAR > } 1998 \text { AND PUBYEAR < } 2014 \text { AND (LIMIT- } \\
\text { TO(AFFILCOUNTRY, "Brazil”)) }\end{array}$ \\
\hline Medline & $\begin{array}{l}\text { ("mild cognitive impairment”[MeSH] OR dementia[MeSH] OR "alzheimer disease"[MeSH]) AND (“"1999/01/01”[PDAT] : "2013/12/31”[PDAT]) } \\
\text { AND medline[sb] AND Brazil[Affiliation]) }\end{array}$ \\
\hline Lilacs & 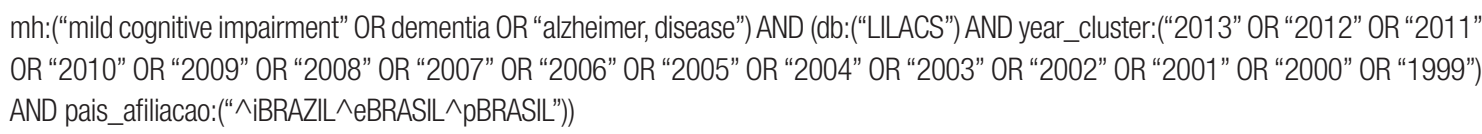 \\
\hline
\end{tabular}




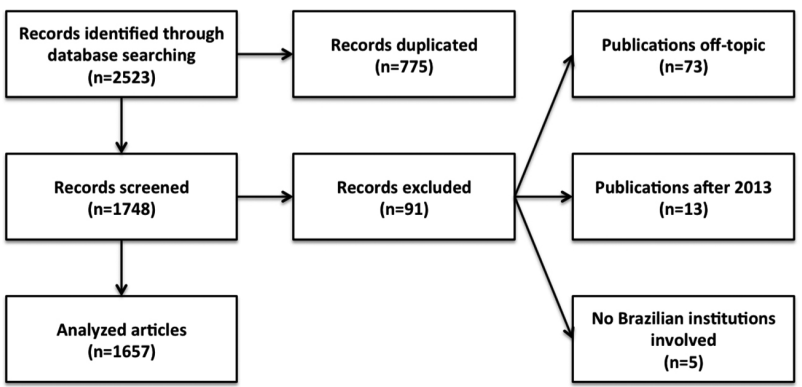

Figure 1. Flowchart of selection process.

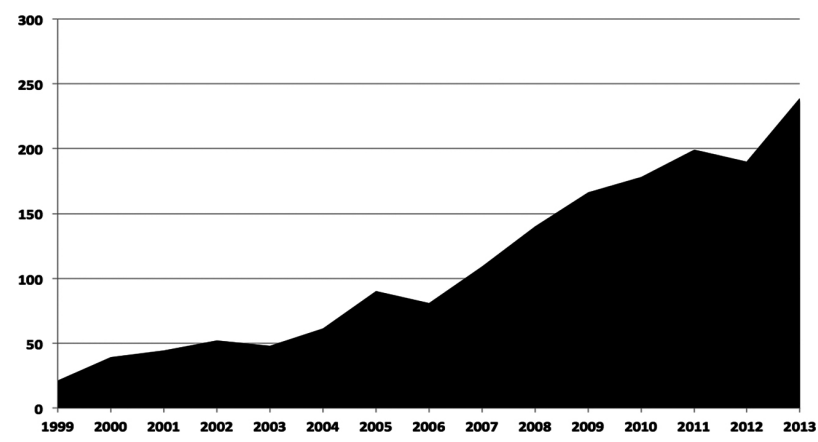

Figure 2. Evolution of publications over a fifteen-year period (1999-2013).

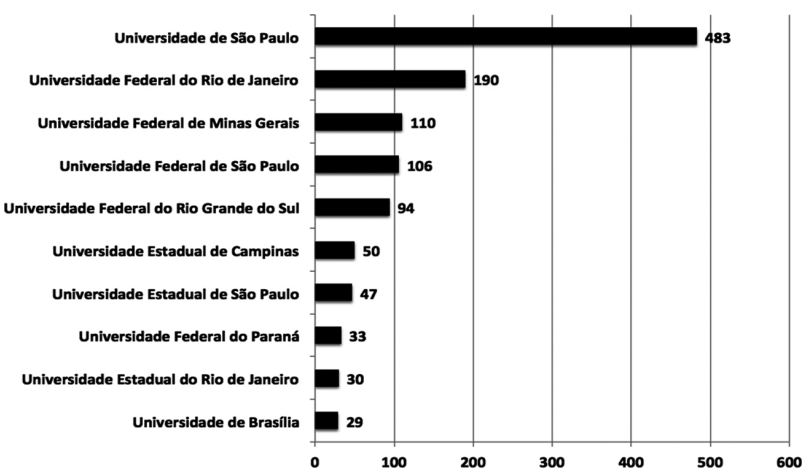

Figure 3. Number of publications according to Brazilian institutions (Top 10).

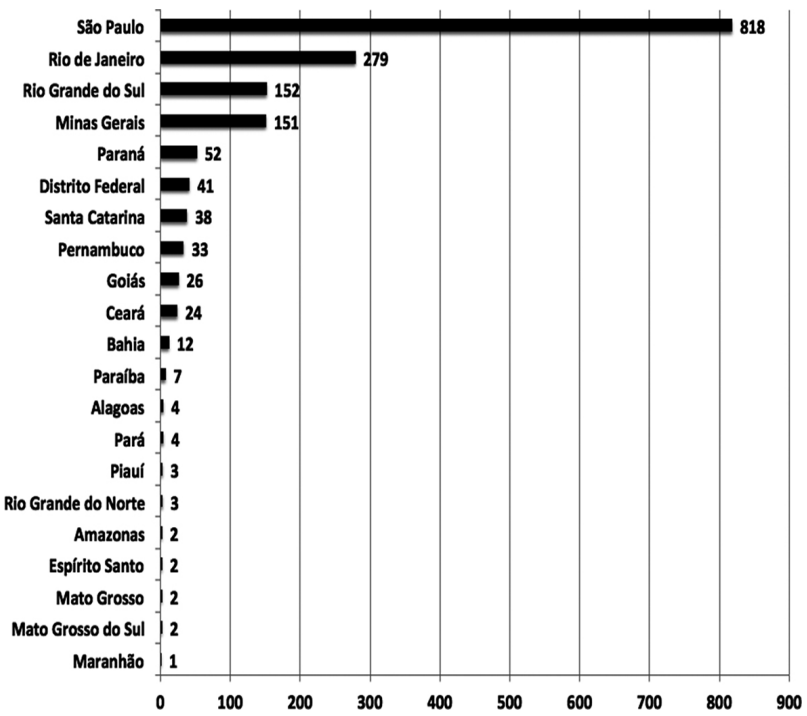

Figure 4. Number of publications according to Brazilian states.
Table 2. Publications by year (1999-2013).

\begin{tabular}{|c|c|c|}
\hline Year & $\mathbf{N}$ & $\%$ \\
\hline 1999 & 21 & 1.27 \\
\hline 2000 & 39 & 2.35 \\
\hline 2001 & 44 & 2.66 \\
\hline 2002 & 52 & 3.14 \\
\hline 2003 & 48 & 2.90 \\
\hline 2004 & 61 & 3.68 \\
\hline 2005 & 90 & 5.43 \\
\hline 2006 & 81 & 4.89 \\
\hline 2007 & 109 & 6.58 \\
\hline 2008 & 140 & 8.45 \\
\hline 2009 & 166 & 10.02 \\
\hline 2010 & 178 & 10.74 \\
\hline 2011 & 199 & 12.01 \\
\hline 2012 & 190 & 11.47 \\
\hline 2013 & 239 & 14.42 \\
\hline Total & 1657 & $100 \%$ \\
\hline
\end{tabular}

Fifty-five percent of publications involved a single Brazilian institution. Twenty-six percent involved two or more Brazilian institutions. Nineteen percent werecollaborative publications involving Brazilian and international institutions (Figure 5). Distribution of publications according to the journal was divided almost equally between Brazilian and international periodicals, with a slight predominance of international journals ( $53 \%$ vs. $47 \%$ ).

Rankings (Top 10) of the most used periodicals for publication are presented in Table 3 and Table 4, in addition to their representativeness amongst publications. When the analysis is focused on these periodicals, Arquivos de Neuro-Psiquiatria and Dementia \& Neuropsychologia rank as the most important Brazilian journals. More than $11 \%$ and $6 \%$ of papers were published in these journals, respectively, over the period. In the same fashion, International Psychogeriatrics ranks as the most representative international periodical, accounting for more than $2 \%$ of the analyzed publications.

In relation to distribution by type of publication, most were original articles focusing on clinical research or literature reviews (Table 5).

\section{DISCUSSION}

Brazil is the South American country with the highest scientific output in Medicine and the number of publications has increased substantially in the last two de- 
Table 3. Distribution of publications in international periodicals (Top 10).

\begin{tabular}{|c|c|c|c|}
\hline International periodicals & Impact Factor* & $\mathbf{N}$ & $\%$ \\
\hline International Psychogeriatrics & 1.892 & 41 & 2.47 \\
\hline Journal of Alzheimer's Disease & 3.612 & 25 & 1.51 \\
\hline International Journal of Geriatric Psychiatry & 3.086 & 18 & 1.09 \\
\hline Dementia and Geriatric Cognitive Disorders & 2.812 & 18 & 1.09 \\
\hline Alzheimer Disease and Associated Disorders & 2.688 & 14 & 0.84 \\
\hline Neurology & 8.303 & 11 & 0.66 \\
\hline PLoS One & 3.534 & 11 & 0.66 \\
\hline Journal of Neural Transmission & 2.871 & 10 & 0.60 \\
\hline Journal of Neurology, Neurosurgery and Psychiatry & 5.580 & 9 & 0.54 \\
\hline Journal of Biological Chemistry & 4.600 & 9 & 0.54 \\
\hline Journal of the American Geriatrics Society & 4.216 & 9 & 0.54 \\
\hline
\end{tabular}

*Impact factor (2013) calculated by Thomson Reuters (Journal Citation Reports®)

Table 4. Distribution of publications in Brazilian periodicals (Top 10).

\begin{tabular}{lccc}
\hline Brazilian periodicals & Impact Factor & N & \% \\
\hline Arquivos de Neuro-Psiquiatria & $1.006^{*}$ & 188 & 11.35 \\
\hline Dementia \& Neuropsychologia & $0.247^{\star *}$ & 108 & 6.52 \\
\hline Revista de Psiquiatria Clínica & $0.886^{*}$ & 68 & 4.10 \\
\hline Revista Brasileira de Psiquiatria & $1.638^{*}$ & 50 & 3.02 \\
\hline Revista Brasileira de Neurologia & NA & 25 & 1.51 \\
\hline Jornal Brasileiro de Psiquiatria & $0.427^{\star *}$ & 24 & 1.45 \\
\hline Revista Brasileira de Medicina & $0.059^{\star *}$ & 23 & 1.39 \\
\hline Clinics & $1.422^{*}$ & 16 & 0.97 \\
\hline Brazilian Journal of Medical and Biological Research & $1.034^{*}$ & 14 & 0.84 \\
\hline Revista Neurociências & $0.135^{\star *}$ & 14 & 0.84 \\
\hline
\end{tabular}

NA: not available, "Impact factor (2013) calculated by Thomson Reuters (Journal Citation Reports®), *Impact factor (2013) calculated by Scopus (SCImago Journal \& Country Rank).

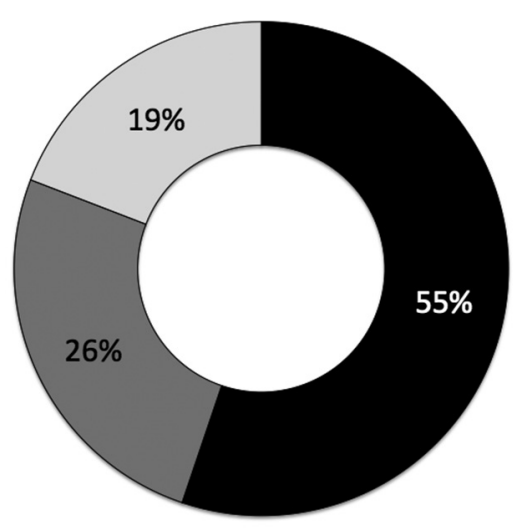

- Publications from a single Brazilian institution

- Publications from two or more Brazilian institutions

$\square$ Publications involving Brazilian and international institutions

Figure 5. Distribution of collaborative and non-collaborative publications.
Table 5. Distribution of types of publication.

\begin{tabular}{lcc}
\hline Type of publication & N & \% \\
\hline Original articles - Clinical & 600 & 36.2 \\
\hline Reviews & 500 & 30.2 \\
\hline Original articles - Basic science & 226 & 13.6 \\
\hline Case reports & 86 & 5.2 \\
\hline Caregiver issues & 76 & 4.6 \\
\hline Original articles - Human genetics & 50 & 3.0 \\
\hline Letter & 44 & 2.7 \\
\hline Original articles - Epidemiology & 31 & 1.9 \\
\hline Editorial & 26 & 1.6 \\
\hline Original articles - Pathology & 10 & 0.6 \\
\hline Not classified & 8 & 0.5 \\
\hline Total & 1657 & $100 \%$ \\
\hline
\end{tabular}


cades, following the same trend of world scientific output over this period. ${ }^{9}$

According to the present review, the overwhelming majority of institutions involved in scientific output on dementia and related disorders were public universities. Moreover, prominent institutions were located mainly in the southeast and south regions, although distribution of researchers throughout Brazilian territory was highly heterogenic, reflecting intrinsic variations within the country.

Our survey shows that output of Brazilian researchers in the area of cognitive disorders increased 4.98-fold from 2003 to 2013 (ten years) and 11.38-fold in the fifteen-year period of analysis (1999-2013). By comparison, in the last 20 years, from 1995 to 2014, the overall scientific output in Brazil increased by a factor of five. ${ }^{10}$

Despite this marked growth, the number of Brazilian scientific publications is still low in comparison to international standards. ${ }^{11}$ This is also true in the area of cognitive impairment and dementia, indicating that efforts are required to improve the output of Brazilian institutions. One possible strategy to accomplish this increase could be to encourage residents to participate in publications of scientific papers during their residence program. ${ }^{12}$

Forty-five percent of publications were collaborative, illustrating the power and importance of research networks converging toward a common interest. Thus, collaboration between different Brazilian universities and research institutions must be pursued by investigators and stimulated by funding agencies. To this end, specific grants aimed at supporting projects in cooperation in the area of cognitive disorders could be part of a national research plan by the federal government in conjunction with state funding agencies. The recent efforts of the Brazilian scientific community in the area of clinical investigation to create a local project within the Alzheimer's Disease Neuroimaging Initiative (ADNI) is also another strategy that might enhance the quality of research in the field.

In conclusion, both quantity and quality of Brazilian publications in international and Brazilian periodicals show a marked evolution in the last 15 years and we hope that this rising trend continues progressively in order to benefit patients not only in Brazil, but also worldwide.

\section{REFERENCES}

1. Herrera E Jr, Caramelli P, Silveira AS, Nitrini R. Epidemiologic survey of dementia in a community-dwelling Brazilian population. Alzheimer Dis Assoc Disord 2002;16:103-108.

2. Bottino CM, Azevedo D Jr, Tatsch M, et al. Estimate of dementia prevalence in a community sample from São Paulo, Brazil. Dement Geriatr Cogn Disord 2008;26:291-299.

3. Chaves ML, Camozzato AL, Godinho C, Piazenski I, Kaye J. Incidence of mild cognitive impairment and Alzheimer disease in Southern Brazil. J Geriatr Psychiatry Neurol 2009;22:181-187.

4. Fagundes SD, Silva MT, Thees MFRS, Pereira MG. Prevalence of dementia among elderly Brazilians: a systematic review. Sao Paulo Med J 2011;129:46-50.

5. Prince PM, Bryce R, Albanese E, Wimo A, Ribeiro W, Ferri CP. The global prevalence of dementia: A systematic review and meta-analysis. Alzheimers Dement 2013;9:63-75.

6. Reitz C, Brayne C, Mayeux R. Epidemiology of Alzheimer disease. Nat Rev Neurol 2011;7:137-152.
7. Nitrini R, Bottino CM, Albala C, et al. Prevalence of dementia in Latin America: a collaborative study of population-based cohorts. Int Psychogeriatr 2009;21:622-630.

8. Sorensen AA. Alzheimer's Disease Research: Scientific Productivity and Impact of the Top 100 Investigators in the Field. J Alzheimer Dis 2009; 16:451-465.

9. Huamaní C, González AG, Curioso WH, Pacheco-Romero J. Scientific production in clinical medicine and international collaboration networks in South American countries. Rev Med Chil 2012;140:466-75.

10. Pinheiro-Machado R, Oliveira RPL. The Brazilian investment in science and technology. Braz J Med Biol Res 2001;34:1521-1530.

11. Van Noorden R. The impact gap: South America by the numbers. Nature 2014;510:202-203.

12. Nitrini R. The scientific production of Brazilian neurologists: 1995-2004. Arq Neuropsiquiatr 2006;64:538-542. 